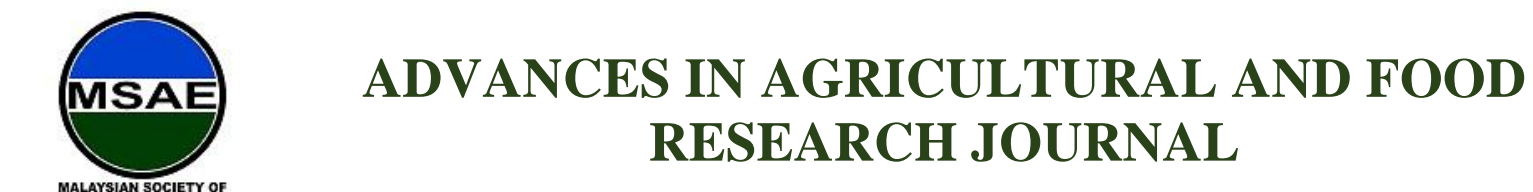

HH PUBLISHER

Short Communication

\title{
Comparison Study on Fiber and Cocopeat from Young Coconut Husks and Old Coconut Husks
}

\author{
Mohd Shahmihaizan Mat Jusoh ${ }^{1 *}$, Mohd Nadzim Nordin², Wan Mohd Aznan Wan Ahamad ${ }^{2}$ \\ ${ }^{1}$ Engineering Research Center, MARDI headquarters, Serdang, Selangor, 43400, Malaysia, \\ shahmi@mardi.gov.my \\ ${ }^{2}$ Director General Office, MARDI Kota Bharu, Kota Bharu, Kelantan, 15710, Malaysia; \\ wmaznan@mardi.gov.my \\ *Corresponding author: Mohd Shahmihaizan bin Mat Jusoh; Engineering Research Center, MARDI \\ headquarters, Serdang, Selangor, 43400, Malaysia; shahmi@mardi.gov.my
}

\begin{abstract}
Fiber and cocopeat are waste products from coconut husks that can be turned into value added products. Fiber and cocopeat from old coconut husks are well known in coconut industry in the world. This paper described fibre strength from young coconut husks, nutrient content and water-holding ability of young coconut cocopeat compared to old coconut cocopeat. The strength of fiber was determined by using Instron Universal Testing Machine. The results showed that mean load at break for young coconut fiber was $13.76 \mathrm{~N}$ while mean load at break for old coconut fiber was $14.93 \mathrm{~N}$. Maximum tensile stress for young coconut fiber was $1.55 \mathrm{MPa}$ and $1.76 \mathrm{MPa}$ for old coconut fiber. The nutrient contents were determined for young cocopeat and old cocopeat resulted as phosphorus (372.79 ppm, 339 ppm), potassium (6829.68 ppm, $10040.46 \mathrm{ppm}$ ), calcium (508.74 ppm, $578.40 \mathrm{ppm})$, magnesium (468.67 ppm, $715.60 \mathrm{ppm}$ ) and sodium (1579.70 ppm, $3917.60 \mathrm{ppm}$ ). The $\mathrm{pH}$ value was 6.55 and 5.39 respectively. The ash contents were $2.62 \%$ for young cocopeat while $4.06 \%$ for old cocopeat. For water holding ability test, moisture content of each sample from young coconut cocopeat and old coconut cocopeat was determined by using soil moisture meter. After seven days with water added $500 \mathrm{ml}$ two times/day, results showed that water holding ability for peat moss was the best while young cocopeat was better than the old cocopeat. All the results showed that fiber and cocopeat from young coconut husk have high potential for sustainable production in the coconut industry.
\end{abstract}

Keywords: fiber; cocopeat; young coconut husk, strength of fiber, nutrient contents, water holding ability

Received: $25^{\text {th }}$ February 2021

Received in revised form: $1^{\text {st }}$ June 2021

Citation: Mat Jusoh, M. S., Nordin, M. N., Wan Ahamad, W. M. A. Comparison study on fiber and cocopeat from young coconut husks and old coconut husks. Adv Agri Food Res J 2021; 2(2): a0000216.

Accepted: $11^{\text {th }}$ June 2021

https://doi.org/10.36877/aafrj.a0000216

\section{Introduction}


Coconut was grown in more than 90 countries. In Malaysia, it was the fourth important crop in acreage after oil palm, rubber and paddy (Christoper, 2018). The coconut industry has significant socio-economic implications as it provides the source of revenues and employment to households. Besides, it supports several vibrant small and medium coconutbased processing industries and exporters.

In Malaysia, 95\% of coconut growers were smallholders with an average yield of 6468 $\mathrm{kg}$ coconuts/hectares in 2019. Coconut production was increased from 2018 to 2019 at 495,531 MT to 527,729 MT (Jabatan Pertanian Semenanjung Malaysia, 2019). The demand for young coconuts begun to emerge with government initiatives, especially the Ministry of Agriculture in the 1990s, to encourage drinking young coconut water (Mohd Rashid et al., 2016).

Young coconuts contain mainly water and a little jelly-like meat instead of the hard white flesh found in mature coconuts. The young coconut drink was a trendy beverage among the community in Malaysia. The higher market price and high market demand have attracted farmers to grow coconut.

Based on the report by Mohd Hafizudin et al. (2016) it was shown that $46.0 \%$ of consumers preferred Pandan varieties and $12.3 \%$ followed by Matag. Another 24\% did not show a tendency to young coconut variety. A total of 32.12 million young coconuts per month were estimated to fulfil the demand based on the study results.

There were two products obtained from coconut husk which are coconut fiber and cocopeat. The coconut fiber can be used as floor mats, doormats, brushes, mattresses, coarse filling material, and upholstery because of its good in stiffness (Yan, 2016). It was also widely used to produce composite material. Another product from husk was cocopeat. The cocopeat was used as a planting media because of its high nutrient content. Cocopeat can be mixed with soil and other media components to make suitable mixes for plant propagation. It was widely used in agriculture, horticulture, and restoration to produce flowers, vegetables, trees, shrubs, and forbs (Alzrog et al., 2013). Two main factors to support quality plant development were good chemical and physical properties of cocopeat. (Awang et al., 2009; Nazari et al., 2011; Paramanandham et al., 2013; Ilahi \& Ahmad, 2017; Udayana et al., 2017; Xiong et al., 2017)

The increase in demand for young coconut has contributed to increased residual products such as coconut husk. Based on production in 2018, as much as $44 \%$ of coconut husk is unutilized and disposed in open field (Tapsir \& Mohd Hafizudin, 2018). The development of processing system for young coconut husk, to process the husk into value-added products such as cocopeat and fiber would overcome this problem. (Mat Jusoh et al., 2020). This 
cocopeat can be sold at RM 7/bag or RM $1.40 / \mathrm{kg}$ while fiber can be sold at RM $1.20 / \mathrm{kg}$ (Mohd Zaffrie et al., 2018).

This paper explained the strength of fiber from young coconut husks and old coconut husk, nutrient content and water holding ability of young coconut cocopeat compared to old coconut cocopeat. The result of this study could be used as a reference for farmers or growers to further expand the use of cocopeat and fiber from young coconut husk.

\section{Materials and Methods}

\subsection{Strength of Fiber from Young and Old Coconut Husks}

\subsubsection{Samples preparation}

The strength of fiber was determined by using Instron Universal Testing Machine as shown in Figure 1 and the experiment was done at Engineering Research Center Laboratory, MARDI Headquarters Serdang. 20 samples were randomly selected consist of old coconut fibers and 20 samples of young coconut fibers both from Matag variety. The fiber was pulled until break occurred as shown in Figure 2.

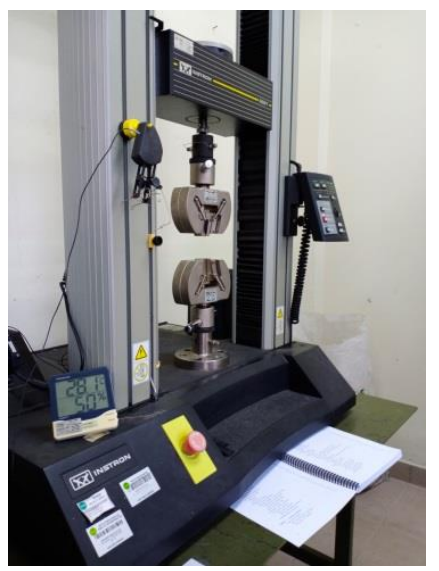

Figure 1. Instron Universal Testing Machine

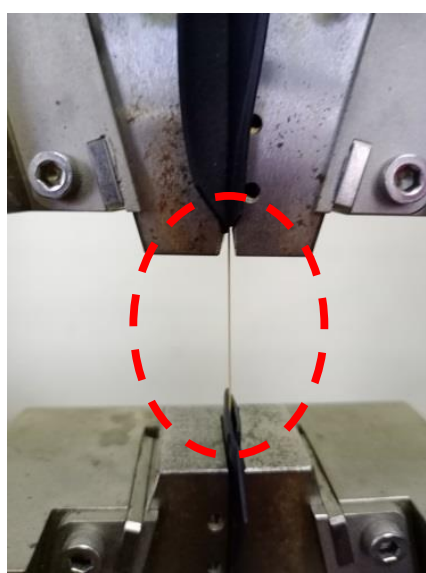

Figure 2. Fiber was pulled till breaks 


\subsubsection{Strength of fibers identification}

A total of 20 samples of each young coconut fibers and old coconut fibers were used for the strength of fibers identification. The fiber was pulled until break occurred for each sample. Data such as the load required to break the fiber was recorded for calculation of fiber strength represented as maximum tensile stress. The maximum tensile stress was determined by using this formula.

$$
\begin{gathered}
\text { Maximum tensile stress, } \sigma(M P a)=\frac{\text { Load at break }(\mathrm{N})}{\text { Area of fiber }\left(\mathrm{m}^{2}\right)} \times 10^{-5} \\
\text { Area of fiber, } A\left(\mathrm{~m}^{2}\right)=\pi r^{2}
\end{gathered}
$$

Where $r$ is the radius of fiber cross section.

\subsection{Nutrients Content Identification}

Both old and young coconut cocopeat samples were delivered to Technical Service Laboratory MARDI Headquarters Serdang for nutrient content identification. The nutrient contents were identified as phosphorus, potassium, calcium, magnesium and sodium. The $\mathrm{pH}$ value and ash content were also determined.

\subsection{Water Holding Ability}

\subsubsection{Samples preparation}

10 samples for each young coconut cocopeat and old coconut cocopeat were prepared in a 6 inches $x 9$ inches polybag as shown in Figure 3. The samples were added with same volume of $500 \mathrm{ml}$ water in the morning and afternoon for a period of 7 days. Moisture content of each sample from young coconut cocopeat and old coconut cocopeat was measured every day before water addition by using soil moisture meter TDR 150 as shown in Figure 4 . These samples were located under a shade in an open structure.

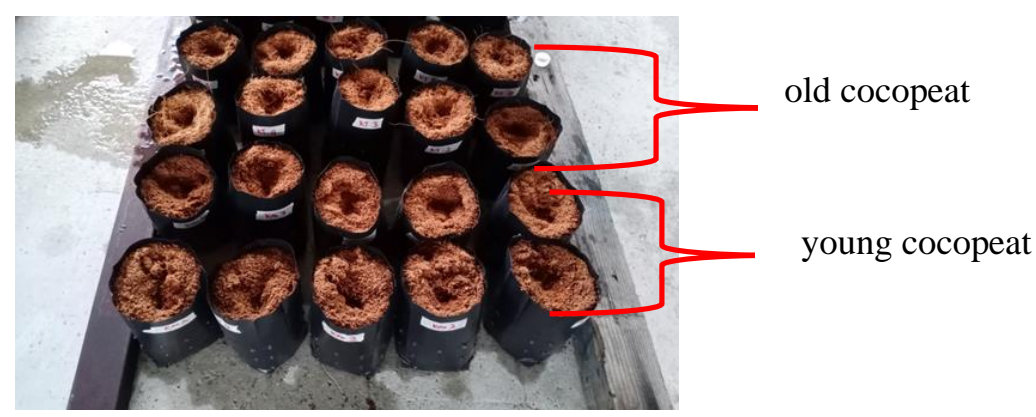

Figure 3. Young coconut cocopeat and old coconut cocopeat samples 


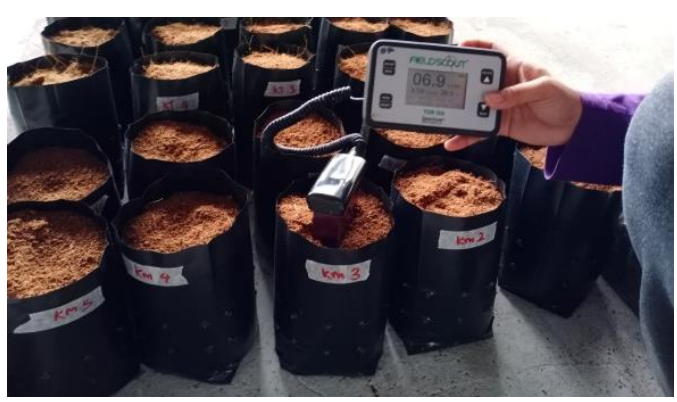

Figure 4. Moisture content measurement.

\subsubsection{Water holding ability calculation}

Each sample moisture content reading was measured for a week to get the water holding ability. The water holding ability was determined by calculation of relative moisture content to the first day. The relative moisture content, $\mathrm{MC}$ was determined by using this formula.

$$
\text { Relative } M C(\%)=M C 2-M C \text { First Day }
$$

Where: MC2 was the current MC reading.

\section{Results and Discussion}

\subsection{Strength of Fiber from Young and Old Coconut Husks}

Table 1 showed results of load at break and maximum tensile stress of young and old coconut fiber. In average, the young coconut fiber broke at a load of $13.76 \mathrm{~N}$ and the maximum tensile stress was recorded as $1.55 \mathrm{MPa}$. The old coconut fiber broke at a load of $14.93 \mathrm{~N}$ and the maximum tensile stress was recorded as $1.76 \mathrm{MPa}$.

Table 1. Results of load at break and maximum tensile stress of young and old coconut fiber

\begin{tabular}{ccc}
\hline Fiber Sample & Load at Break, F $(\mathbf{N})$ & $\begin{array}{c}\text { Maximum Tensile } \\
\text { stress, } \boldsymbol{\sigma}(\mathbf{M P a})\end{array}$ \\
\hline Young Coconut & 13.76 & 1.55 \\
Old Coconut & 14.93 & 1.76 \\
\hline
\end{tabular}

A statistical analysis was performed by using Minitab Software to identify the significant difference between the average load at break for the young and old coconut fiber. Two samples $T$-test was performed with confidence interval of $95 \%$, the samples were assumed with equal variance. The $P$-value obtained was $0.559>0.05$, so there was no significant difference for average load at break for the young and old coconut fiber. This result concludes that young coconut fiber's strength was similar to old coconut fiber as shown in Figure 5. 


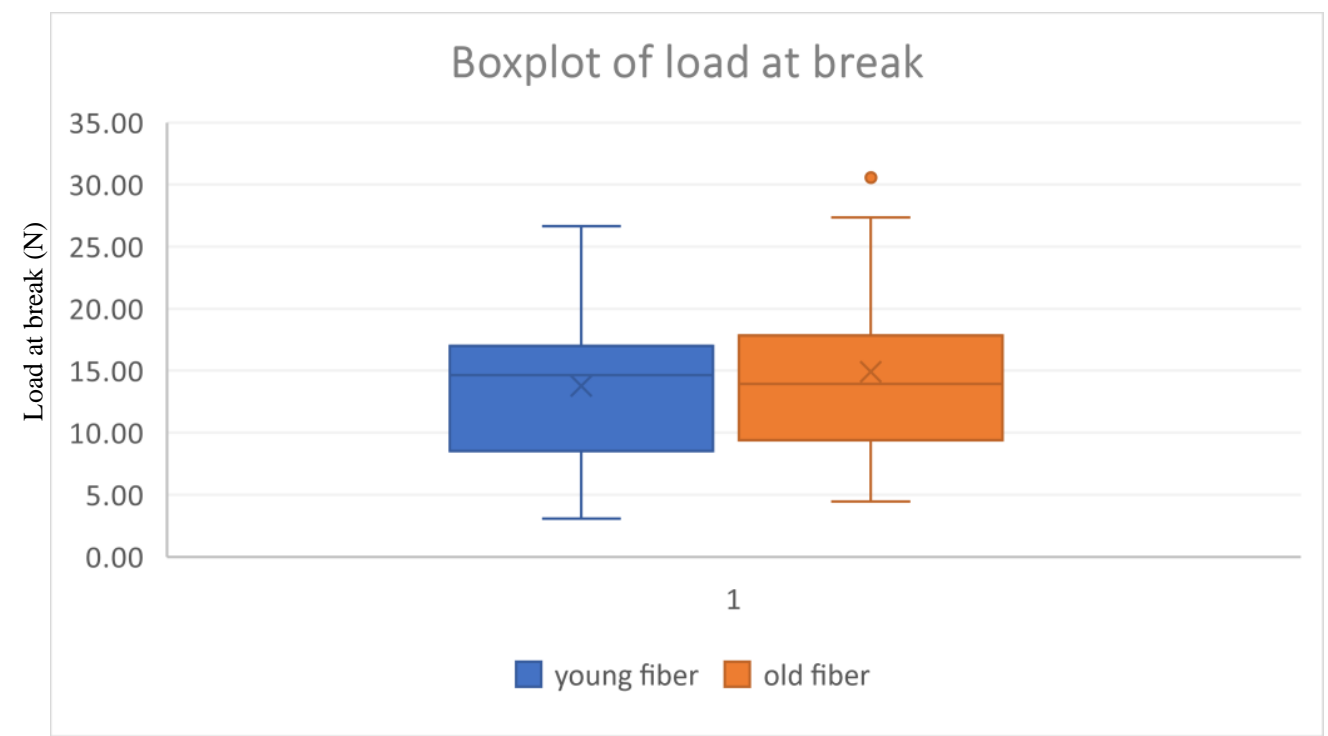

Figure 5. Boxplot of load at break for young and old coconut fiber

\subsection{Nutrients Content}

The nutrient contents were determined for young cocopeat and old cocopeat resulted as in Table 2. The phosphorus and calcium content in young cocopeat was similar to old cocopeat. Other nutrients content had huge different for young and old cocopeat. These nutrients content was important parameter to proof that both young and old cocopeats were suitable for planting crops. The $\mathrm{pH}$ value was 6.55 and 5.39 respectively indicates that young cocopeat almost neutral and good as planting media. The ash contents were $2.62 \%$ for young cocopeat while $4.06 \%$ for old cocopeat.

Table 2. Nutrients content for old and young cocopeat

\begin{tabular}{ccc}
\hline Nutrients & young cocopeat & old cocopeat \\
\hline Phosphorus (P) & $372.79 \mathrm{ppm}$ & $339 \mathrm{ppm}$ \\
Potassium $(\mathrm{K})$ & $6829.68 \mathrm{ppm}$ & $10040.46 \mathrm{ppm}$ \\
calcium & $508.74 \mathrm{ppm}$ & $578.40 \mathrm{ppm}$ \\
magnesium & $468.67 \mathrm{ppm}$ & $715.60 \mathrm{ppm}$ \\
sodium & $1579.70 \mathrm{ppm}$ & $3917.60 \mathrm{ppm}$ \\
\hline
\end{tabular}

\subsection{Water Holding Ability}

A statistical analysis was performed using Minitab Software to identify the significant difference of relative moisture content between old cocopeat and young cocopeat. Two samples $T$-test was performed with confidence interval of $95 \%$, the samples were assumed with equal variance. The $P$-value obtained was 0.034 which was less than 0.05 , so there was 
significant difference for relative moisture content between old cocopeat and young cocopeat. The boxplot was shown in Figure 6.

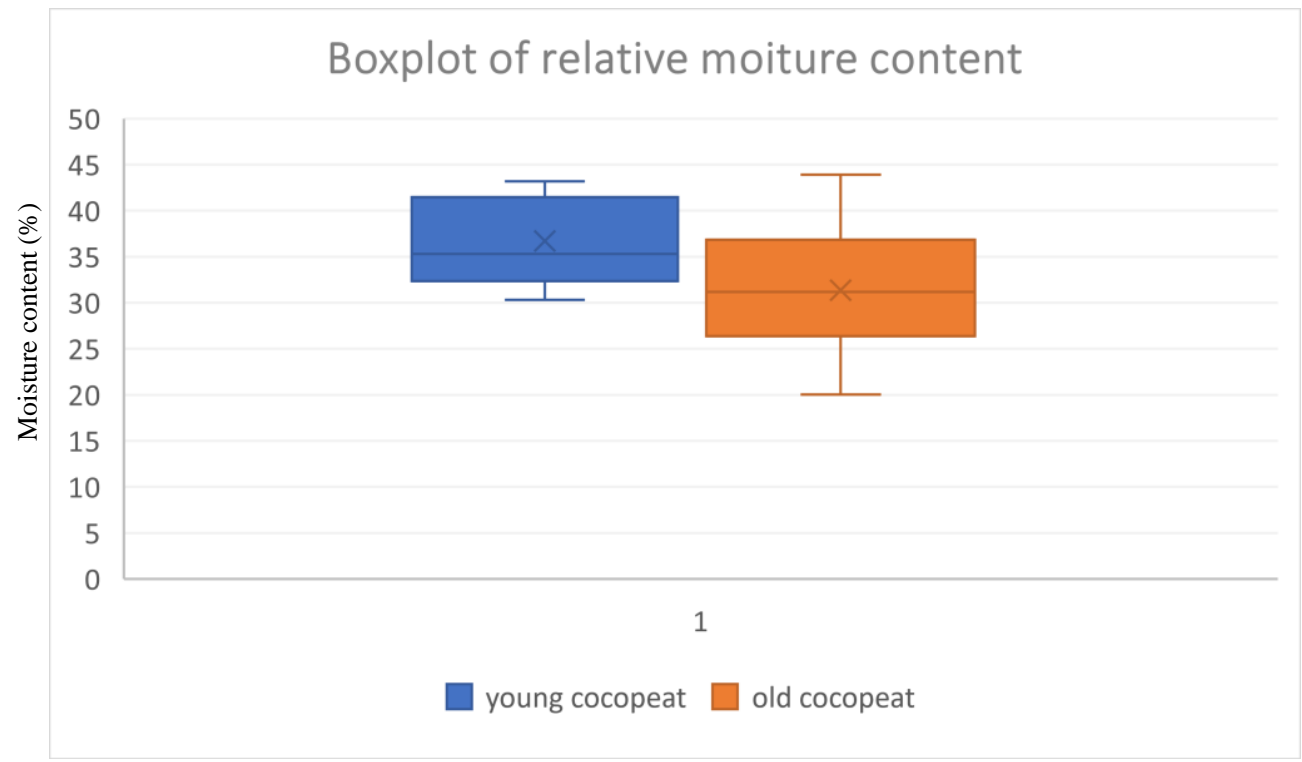

Figure 6. Boxplot of relative moisture content of old and young cocopeat

Figure 7 showed the result of water holding ability for old coconut cocopeat and young coconut cocopeat. Young cocopeat holding ability increased and better holding ability compared to old coconut cocopeat. From this graph, it can be concluded that young coconut cocopeat was better in water holding ability compared to the old coconut cocopeat. This water holding ability was very important factor for media planting material.

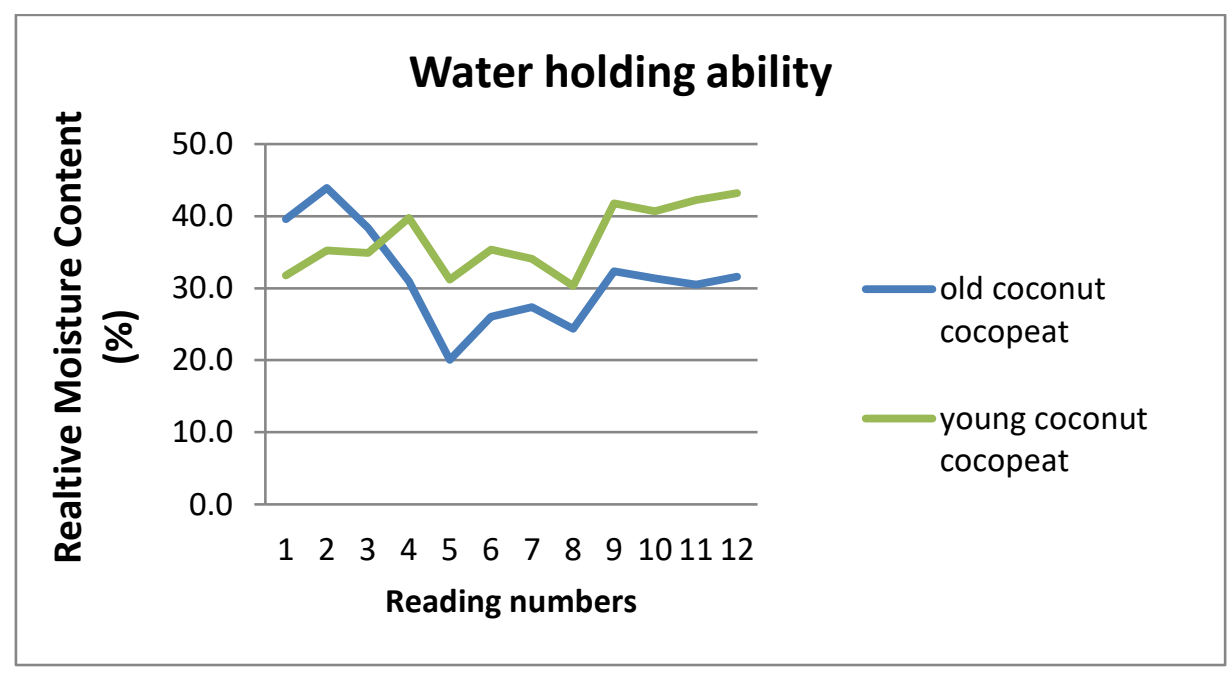

Figure 7. Result of water holding ability for old cocopeat and young cocopeat

\section{Conclusion}

Young coconut fiber has a good strength and comparable to the old coconut fiber and should be utilized in coconut industry as a value added product similar to fiber used from the 
old coconut cocopeat. There were also similar nutrients contents in the young coconut cocopeat compare to the old coconut cocopeat. Moreover, there was less ash in the young coconut cocopeat thus making it better than the old coconut cocopeat. For water holding ability, the young coconut cocopeat was better in performance compared to the old coconut cocopeat. For future study or research, growth performance of crop using the young cocopeat should be performed to strengthen the facts that the young coconut cocopeat be used in industry.

Supplementary Materials: The following are available online at http://www.journals.hhpublisher.com/index.php/AAFRJ//xxx/s1, Figure S1: title, Table S1: title.

Author Contributions: Conceptualization, Mohd Shahmihaizan bin Mat Jusoh. and Wan Mohd Aznan bin Wan Ahamad.; methodology, Mohd Shahmihaizan bin Mat Jusoh.; software, Mohd Shahmihaizan bin Mat Jusoh.; validation Md. Akhir bin Hamid ${ }^{3}$.formal analysis Mohd Shahmihaizan bin Mat Jusoh, Mohd Nadzim bin Nordin.; investigation, Mohd Shahmihaizan bin Mat Jusoh.; resources, Mohd Shahmihaizan bin Mat Jusoh.; data curation, Mohd Shahmihaizan bin Mat Jusoh.; writing—original draft preparation, Mohd Shahmihaizan bin Mat Jusoh.; writing — review and editing, Mohd Nadzim bin Nordin, Md. Akhir bin Hamid and Wan Mohd Aznan bin Wan Ahamad.;

Funding: This work was funded by 11th Malaysian Plan Development Fund under the code of P-RM 413.

Acknowledgments: The authors would like to gratefully acknowledge MARDI for funding this project. The appreciation also extended for assistant researchers Norahshekin binti Abdul Rahman, Ahmad Kamil bin Zolkafli, Bunyamin bin Abu Kassim, Humaizi bin Md Jamin who assisted during operations and experiments. My gratitude as well to others either directly or indirectly involved in the study.

Conflicts of Interest: The authors declare no conflict of interest.

\section{References}

Alzrog, A. M., Mohamed, A. S., Zakaria, R., et al. (2013). Effect of planting media (rice husk and coco peat) on the uptake of cadmium and some micronutrients in chilli (Capsicum annum L.). Pure and Applied Biology, 2, 76-82.

Awang, Y., Shaharom, A. S., Mohamad, R. B., et al. (2009). Chemical and physical characteristics of cocopeat-based media mixtures and their effects on the growth and development of Celosia cristata. American Journal of Agricultural and Biological Sciences, 4, 63-71.

Christoper, J. B. (2018). Implementation of coconut policies and initiatives: The real challenges to empower the industry. National Coconut Conference, Ipoh Perak.

Ilahi, W. F. F., Ahmad, D. (2017). A study on the physical and hydraulic characteristics of cocopeat perlite mixture as a growing media in containerized plant production. Sains Malaysiana. 46, 975-980.

Jabatan Pertanian Semenanjung Malaysia. (2019). Booklet statistic tanaman (sub-sektor tanaman makanan) 2019 [PDFfile]. Retrieved from http://www.doa.gov.my/index/resources/aktiviti_sumber/sumber_awam/maklumat_pertanian/perang kaan_tanaman/booklet_statistik_tanaman_2019.pdf

Mohd Hafizudin, Z., Mohd Zaffrie, M. A., Nor Amna A'liah, M. N., et al. (2016). Kajian potensi dan kecenderungan pengguna terhadap kelapa segar dan Produk Makanan Berasaskan Kelapa (PMBK) di Malaysia, Laporan Kajian Sosioekonomi 2016. 
Mohd Rashid, R., Nor Amna A'liah, M. N., Mohd Hafizudin, Z., et al. (2016). Potensi pembangunan industri kelapa negara dari perspektif rantaian nilai, Laporan Kajian Sosioekonomi 2016.

Mat Jusoh, M. S., Wan Ahamad, W. M. A., Nordin, M. N., et al. (2020). Development of Efficient Processing System for Young Coconut Husk. Advances In Agricultural and Food Research Journal 2020, 1(2).

Mohd Zaffrie, M.A., Mohd Hafizudin Z., Azahar H. (2018). The market potential of non-food coconut-based products in Malaysia, National Coconut Conference, 7-9 August 2018, Ipoh Perak. eISBN 978-967936-663-1

Nazari, F., Farahmand, H., Khosh-Khui, M., et al. (2011). Effects of coir as a component of potting media on growth, flowering and physiological characteristics of hyacinth (Hyacinthus orientalis L. cv. Sonbole-Irani). International Journal of Agricultural and Food Science, 1, 34-38.

Paramanandham, J., Ross, P. R., Vaidehi, J., et al. (2013). Influence of sequential washing on the $\mathrm{pH}$ and electrical conductivity of graded coir pith. International Journal of Pure and Applied Zoology. 3: 231234.

Tapsir, S., Mohd Hafizudin, Z. (2018). Industry outlook and consumer preference for fresh and processed coconut products. National Coconut Conference, Ipoh Perak.

Udayana, S. K., Naorem, A., Singh, N. A. (2017). The multipurpose utilization of coconut by-products in agriculture: prospects and concerns. International Journal of Current Microbiology and Applied Sciences, 6, 1408-1415.

Yan, Y. (2016). Chapter Developments in fibers for technical nonwovens. In Advances in Technical Nonwovens. Woodhead Publishing Series in Textiles. pp. 19-96. 